\title{
Clustering Data Antropometri Balita Untuk Menentukan Status Gizi Balita Di Kelurahan Jumput Rejo Sukodono Sidoarjo
}

\author{
Amir Ali ${ }^{1}$ \\ ${ }^{1}$ Rekam Medis dan Informasi Kesehatan Stikes Yayasan Rumah Sakit Dr.Soetomo \\ Prof Dr.Moestopo 8A Surabaya \\ amir.consulting@gmail.com
}

\begin{abstract}
Abstrak
Menurut data dari Buku Profil Kesehatan Kabupaten Sidoarjo tahun 2018 dimana di kecamatan sukodono kelurahan jumput rejo, dari hasil penimbangan dapat diketahui bahwa balita dengan status Bawah Garis Merah (BGM) sebesar 733 (0.6\%) dengan rincian anak balita laki-laki 344 orang dan balita perempuan 388 orang. Hal ini mengindikasikan masih adanya balita dengan status gizi buruk. Pemantauan pertumbuhan fisik anak dilakukan dengan menggunakan parameter diantaranya ukuran antropometrik. indeks antropometri yang digunakan yaitu berat badan menurut umur (BB/U), tinggi badan menurut umur $(T B / U)$. Tujuan dari penelitian ini adalah untuk melakukan pengelompokan data antropometri balita dalam menentukan status gizinya di lingkungan Kelurahan Jumput Rejo Kecamatan Sukodono Kabupaten Sidoarjo. Metode yang digunakan menggunakan teknik data mining dengan algoritma K-Means. Penelitian ini menghasilkan 5 cluster dimana jumlah balita pada cluster 1 $=37$ balita, pada cluster 2 sejumlah $=30$ balita, pada cluster 3 terdapat 28 balita . Sedangkan pada cluster 4 berjumlah 33 balita, serta pada cluster 5 sejumlah 22 balita. Hasil pengelompokkan data antropometri balita di desa jumput rejo sukodono menunjukkan bahwa terdapat bayi dengan status gizi buruk sebanyak 37 balita, gizi kurang sebanyak 30 balita, gizi baik sebanyak 28 balita, gizi lebih sebanyak 33 balita dan 22 balita mengalami obesitas dari total 150 data antropometri balita.
\end{abstract}

Kata kunci: Clustering, algoritma, K-Means, Data Mining, Status Gizi

Abstract

According to data from the Health Profile Book of Sidoarjo Regency in 2018, in the sub-district of Sukodono, Jumput Rejo village, from the results of the weighing it can be seen that children under the Red Line (BGM) status are 733 (0.6\%) with details of 344 boys and toddlers. 388 women. This indicates that there are still toddlers with poor nutritional status. Monitoring of children's physical growth was carried out using parameters including anthropometric measurements. Anthropometric indexes used were body weight for age (BW / $U)$, height for age $(T B / U)$. The purpose of this study was to group the anthropometric data of toddlers in determining their nutritional status in Jumput Rejo Village, Sukodono District, Sidoarjo Regency. The method used is using data mining techniques with the K-Means algorithm. This study resulted in 5 clusters where the number of children under five in cluster1 $=37$ children, in cluster 2 a number of $=30$ children under five, in cluster 3 there were 28 children under five. While in cluster 4 there are 33 children under five, and in cluster 5 there are 22 children under five. The results of grouping the anthropometric data for toddlers in the village of Jumput Rejo Sukodono show that there are 37 infants with malnutrition status, 30 under-fives with poor nutrition, 28 under-fives with good nutrition, 33 under-fives and 22 under-fives who are obese from a total of 150 anthropometric data. 
Keywords: Clustering, algorithms, K-Means, Data Mining, Nutritional Status

\section{PENDAHULUAN}

Berdasarkan Buku Profil Kesehatan Kabupaten Sidoarjo tahun 2018, pada empat tahun terakhir tren gizi buruk selalu naik.

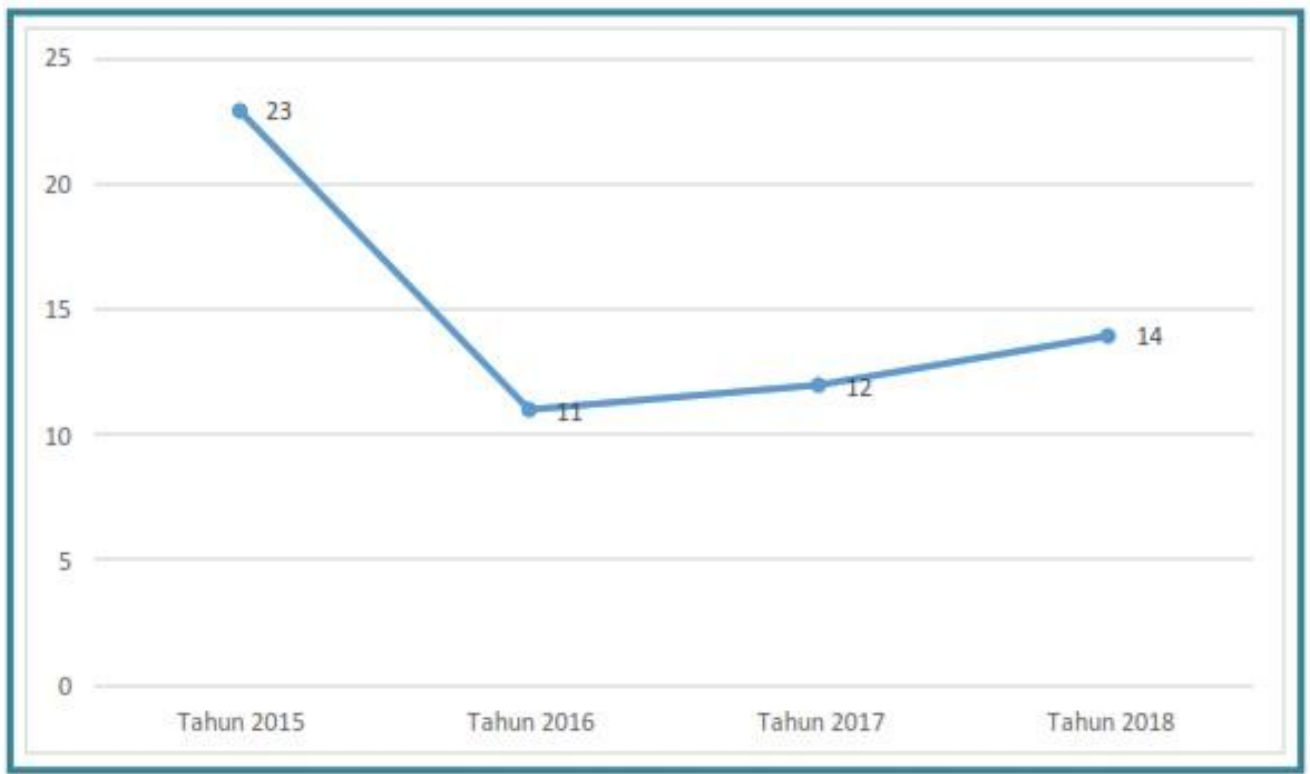

Sumber : Seksi Kesga dan Gizi Dinkes Kabupaten Sidoarjo

Gambar 1. Grafik Tren Balita Gizi Buruk di Kabupaten Sidoarjo Tahun 2015-2018

Dari gambaran diatas maka dapat kita ambil kesimpulan mulai tahun 2016 sampai 2018 gizi buruk pada balita terus meningkat, walaupun jumlahnya tidak banyak. Jika melihat dari grafik tren balita gizi buruk di Kabupaten Sidoarjo, maka ini terdapat masalah gizi pada balita. Hal ini didukung dengan data dari Buku Profil Kesehatan Kabupaten Sidoarjo tahun 2018 dimana di kabupaten Sidoarjo pada tahun 2018, jumlah balita sebesar 175.393 dengan balita yang ditimbang 118.464. Dari hasil penimbangan dapat diketahui bahwa balita dengan status Bawah Garis Merah (BGM) sebesar 733 (0.6\%) dengan rincian anak balita laki-laki 344 orang dan balita perempuan 388 orang. Hal ini mengindikasikan masih adanya balita dengan status gizi buruk. Hal ini perlu diteliti mengapa masalah status gizi di Kabupaten Sidoarjo masih terdapat status gizi buruk pada balita. Pemahaman masyarakat khususnya ibu dari balita akan status gizi baik, lebih, buruk dan kurang masih minim. Ditambah dengan ibu dari balita yang malas ke posyandu untuk memeriksakan balitanya menjadi satu faktor terjadinya gizi buruk, karena pemahaman akan status gizi yang masih rendah di kalangan masyarakat khusunya ibu dari balita tersebut. pada penelitian ini, kami mencoba menemukan karakteristik penting dari data antropometri balita yang tersimpan dalam database bidan puskesmas Kecamatan Sukodono untuk dianalisa dan diolah agar dapat ditemukan pengetahuan baru yang manfaatnya dapat dirasakan oleh masyarakat di lingkungan Kelurahan Jumput Rejo Kecamatan Sukodono Kabupaten Sidoarjo atau dengan istilah lain knowledge discovery in database.

Amir Ali, [Clustering Data Antropometri Balita Untuk Menentukan Status Gizi Balita di Kelurahan Jumput Rejo Sukodono Sidoarjo] 
Secara umum antropometri artinya ukuran tubuh manusia. Ditinjau dari sudut pandang gizi, maka antropometri gizi berhubungan dengan berbagai macam pengukuran dimensi tubuh dan komposisi tubuh dari berbagai tingkat umur dan tingkat gizi. Antropometri secara umum digunakan untuk melihat ketidakseimbangan asupan protein dan energi. Hal ini terlihat pada pola pertumbuhan fisik dan proporsi jaringan tubuh seperti lemak, otot dan jumlah air dalam tubuh [1]. Pengukuran antropometri dibedakan menjadi 2 kelompok, yaitu ukuran yang tergantung usia dan ukuran yang tidak tergantung usia. Pengukuran tergantung pada usia yaitu berat badan terhadap usia $(\mathrm{BB} / \mathrm{U})$, tinggi badan terhadap usia $(\mathrm{TB} / \mathrm{U})$, lingkar kepala terhadap usia $(\mathrm{LK} / \mathrm{U})$, dan lingkar lengan atas terhadap usia (LLA/U). Pengukuran status gizi yang tergantung dengan usia memiliki kesulitan. Kesulitan yang sering didapati adalah kurang tepatnya menentukan usia anak. Ketidaktepatan dapat dikarenakan tidak semua anak memiliki catatan tanggal [2].

Penelitian ini melakukan klasterisasi data hasil pengukuran antropometri balita menggunakan K-Means clustering. Pada contoh penelitian yang dilakukan oleh Eni Irfiani dkk terkait algoritma K-Means clustering untuk menentukan nilai gizi balita ditemukan masih terdapat $30 \%$ balita obesitas dan $11 \%$ kekurangan gizi, untuk itu perlu adanya penanganan dan perhatian dari kader Posyandu dan Puskesmas terkait kepada orang tua balita tersebut. Hal ini dimana dengan klasterisasi menggunakan algoritma K-Means dapat mengklasifikasi nilai gizi balita secara umum agar dapat digunakan sebagai landasan pencegahan dini bagi para kader posyandu menanggulangi gizi buruk serta obesitas [3]

\section{METODE PENELITIAN}

Data mining merupakan sebuah proses yang menggunakan teknik statistik, matematika, kecerdasan buatan, dan machine learning yang mengekstraksi dan mengidentifikasi informasi yang bermanfaat dan pengetahuan yang terakit dari berbagai database yang besar [4]. Secara garis besar, data mining dapat dikelompokkan menjadi 2 kategori utama [5] yaitu:

1. Descriptive mining yaitu proses untuk menemukan karakteristik penting dari data dalam satu basis data. Teknik data mining yang termasuk descriptive mining adalah clustering, asosiation dan sequential mining

2. Predictive yaitu proses untuk menemukan pola dari data dengan menggunakan beberapa variabel lain di masa depan. Salah satu teknik yang terdapat dalam predictive mining adalah klasifikasi.

Clustering atau pengklasteran adalah suatu teknik data mining yang digunakan untuk menganalisis data untuk memecahkan permasalahan dalam pengelompokkan data atau lebih tepatnya mempartisi dari dataset ke dalam subset. Pada teknik clustering targetnya adalah untuk kasus pendistribusian (objek, orang, peristiwa dan lainnya) ke dalam suatu kelompok, hingga derajat tingkat keterhubungan antar anggota cluster yang sama adalah kuat dan lemah antara anggota cluster yang berbeda [6]

Teknik cluster mempunyai dua metode dalam pengelompokkannya yaitu hierarchical clustering dan non-hierarchical clustering. hierarchical clustering merupakan suatu metode pengelompokkan data yang cara kerjanya dengan mengelompokkan dua data atau lebih yang mempunyai kesamaan atau kemiripan, kemudian proses dilanjutkan ke objek lain yang mimiliki kedekatan dua, proses ini terus berlangsung hingga cluster membentuk semacam tree dimana ada hirarki atau tingkatan yang jelas antar objek dari yang paling mirip hingga yang paling tidak mirip. Namun secara logika semua objek pada akhirnya hanya akan membentuk sebuah cluster.

Amir Ali, [Clustering Data Antropometri Balita Untuk Menentukan Status Gizi Balita di Kelurahan Jumput Rejo Sukodono Sidoarjo] 
Sedangkan non-hierarchical clustering pada teknik ini dimulai dengan menentukan jumlah cluster yang diinginkan (dua cluster, tiga cluster, empat cluster atau lebih), setelah jumlah yang cluster yang diinginkan maka proses cluster dimulai tanpa mengikuti proses hirarki, metode ini juga sering disebut sebagai metode $K$-Means Clustering [7]

Metode $K$-Means banyak digunakan karena memiliki beberapa kelebihan. Mulai dari mudah untuk diimplementasikan dan dijalankan, waktu yang dibutuhkan untuk menjalankan relatif cepat, mudah diadaptasi dan umum digunakan [8]. Metode K-Means memiliki karakteristik yaitu merupakan metode pengelompokan yang sederhana dan dapat digunakan dengan mudah, pada jenis data set tertentu, K-Means tidak dapat melakukan segmentasi data dengan baik di mana hasil segmentasi tidak dapat menentukan pola kelompok yang mewakili karakteristik bentuk alami data, $K$-Means bisa mengalami masalah ketika mengelompokkan data yang mengandung outlier [9]. Metode K-Means Clustering merupakan metode yang paling popular dan banyak digunakan pada proses klusterisasi data. Metode K-Means Clustering membagi data menjadi beberapa kelompok serta dapat menerima masukan berupa data tanpa label kelas [10]. K-Means Clustering merupakan salah satu metode data clustering non-hirarki yang mengelompokan data dalam bentuk satu atau lebih cluster/kelompok. Data-data yang memiliki karakteristik yang sama dikelompokan dalam satu cluster/kelompok dan data yang memiliki karakteristik yang berbeda dikelompokan dengan cluster/kelompok yang lain sehingga data yang berada dalam satu cluster/kelompok memiliki tingkat variasi yang kecil [11]. Algoritma ini mampu meminimalkan jarak antara data ke clusternya. Pada dasarnya penggunaan algoritma ini dalam proses clustering tergantung pada data yang didapatkan dan konklusi yang ingin dicapai di akhir proses [6]

Dalam mengukur jarak antara titik pusat atau centroid dengan data adalah dengan menggunakan euclidean distance. Perhitungan untuk euclidean distance menggunakan persamaan (1): [12]

$$
d_{i k}=\sqrt{\sum_{j=1}^{m}\left(x_{i j}-c_{k j}\right)^{2}}
$$

Dengan:

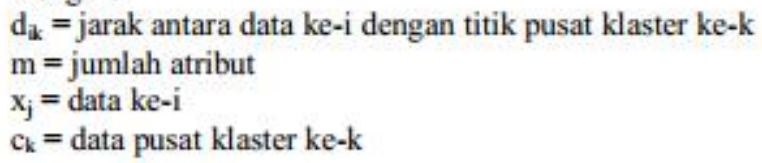

Tools yang akan digunakan untuk membantu proses clustering menggunakan aplikasi Weka. WEKA (Waikato Environment for Knowledge Analysis) merupakan perangkat lunak data mining yang dikembangkan oleh Universitas Waikato, New Zealand. Diimplementasikan pertama kali pada tahun 1997 dan mulai menjadi open source pada tahun 1999 [13]. WEKA terdiri dari beberapa tools yang dapat digunakan untuk melakukan tugas pre-processing data, classification, regression, klustering, association rules, dan visualisasi [14]

Rancangan pada penelitian ini dimulai dari identifikasi permasalahan, pengumpulan data hasil pengukuran antropometri balita, menganalisa datanya dan mengelompokkan datanya berdasarkan parameter yang diambilkan dari data sekunder antropometri balita sehingga nantinya dapat digunakan untuk mengelompokkan status gizi tiap balita.

Penelitian ini melakukan klasterisasi data hasil pengukuran antropometri balita menggunakan $K$-Means clustering. Attribut data antropometri balita yang akan dianalisa yaitu:

1. Berat Badan $(\mathrm{BB} / \mathrm{U})$

2. Tinggi Badan $(\mathrm{TB} / \mathrm{U})$

Amir Ali, [Clustering Data Antropometri Balita Untuk Menentukan Status Gizi Balita di Kelurahan Jumput Rejo Sukodono Sidoarjo] 
Attribut diatas akan dijadikan inputan dan diproses untuk mendapatkan informasi baru terkait karakteristik dari data antropometri balita yang berkunjung ke Posyandu di Kelurahan Jumput Rejo Kecamatan Sukodono Kabupaten Sidoarjo. Output dari penelitian ini adalah berupa karakteristik yang dihasilkan dari informasi baru yang digali dari data antropometri balita. karakteristik tersebut bisa berupa sejumlah kelompok berat badan dan tinggi badan balita yang bersangkutan. Metode yang digunakan dalam penelitian ini yaitu $\mathrm{K}$-Means Clustering.

Algoritma K-Means hanya mengambil sebagian dari banyaknya komponen yang didapatkan untuk kemudian dijadikan pusat cluster awal, pada penentuan pusat cluster ini dipilih secara acak dari populasi data. Kemudian algoritma $k$-means akan menguji masing masing dari setiap komponen dalam populasi data tersebut dan menandai komponen tersebut ke dalam salah satu pusat cluster yang telah didefinisikan sebelumnya tergantung dari jarak minimum antar komponen dengan tiap-tiap pusat cluster [15]. Jarak minimum antar komponen dengan tiap pusat cluster dihitung dengan menggunakan rumus euclidean distance. Selanjutnya posisi pusat cluster akan dihitung kembali sampai semua komponen data digolongkan ke dalam tiap - tiap cluster dan terakhir akan terbentuk cluster baru [15]. Cluster yang terbentuk akan menginformasikan informasi baru terkait karakteristik dari data antropometri balita yg berkunjung ke posyandu di Kelurahan Jumput Rejo Kecamatan Sukodono Sidoarjo. Karakteristik tersebut bisa berupa sejumlah berat badan dan tinggi badan balita yang nantinya akan menginformasikan terkait status gizi tiap balita. Informasi status gizi balita tersebut merupakan output dari penelitian ini.

\section{Flowchart dari algoritma K-Means Clustering [16]}

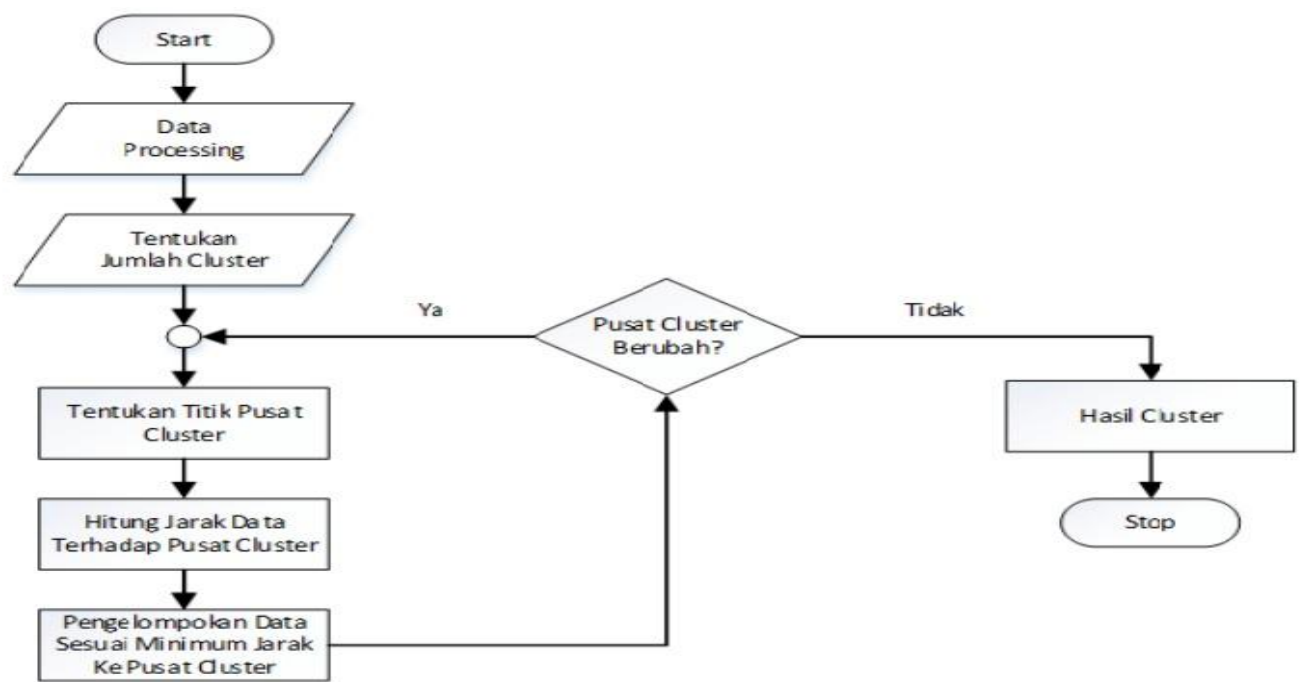

Gambar 2. Flowchart Algoritma K-Means

Amir Ali, [Clustering Data Antropometri Balita Untuk Menentukan Status Gizi Balita di Kelurahan Jumput Rejo Sukodono Sidoarjo] 


\section{HASIL DAN PEMBAHASAN}

Tabel 1. Hasil Clustering

\begin{tabular}{|c|c|c|}
\hline Hasil Cluster 1 & Hasil Cluster 2 & Hasil Cluster 3 \\
\hline $\begin{array}{l}\text { Terdiri dari } 37 \text { balita yang } \\
\text { berasal dari, Posyandu : } \\
\text { 1. Ciro } 1=2 \\
\text { 2. Kedung } 1=1 \\
\text { 3. Jumput Wetan }=7 \\
\text { 4. Ciro } 2=0 \\
\text { 5. Citra Gading = } 11 \\
\text { 6. Citra Surya Mas = } 2 \\
\text { 7. Jumput Rejo Indah }=3 \\
\text { 8. Keling = } 6 \\
\text { 9. Puri Sejahtera } 3=3 \\
\text { 10. Surya Asri } 2 \mathrm{~B}=2\end{array}$ & $\begin{array}{l}\text { Terdiri dari } 30 \text { balita yang } \\
\text { berasal dari, Posyandu : } \\
\text { 1. Ciro } 1=5 \\
\text { 2. Kedung } 1=0 \\
\text { 3. Jumput Wetan }=0 \\
\text { 4. Ciro } 2=0 \\
\text { 5. Citra Gading }=0 \\
\text { 6. Citra Surya Mas }=3 \\
\text { 7. Jumput Rejo Indah }=3 \\
\text { 8. Keling }=6 \\
\text { 9. Puri Sejahtera } 3=7 \\
\text { 10. Surya Asri } 2 \mathrm{~B}=6\end{array}$ & $\begin{array}{ll}\text { Terdiri dari } 28 \text { Balita yang } \\
\text { berasal dari, Posyandu : } \\
\text { 1. } & \text { Ciro } 1=5 \\
\text { 2. } & \text { Kedung } 1=0 \\
\text { 3. } & \text { Jumput Wetan }=0 \\
\text { 4. } & \text { Ciro } 2=0 \\
\text { 5. } & \text { Citra Gading }=0 \\
\text { 6. } & \text { Citra Surya Mas }=6 \\
\text { 7. } & \text { Jumput Rejo Indah = 5 } \\
\text { 8. } & \text { Keling }=0 \\
\text { 9. } & \text { Puri Sejahtera } 3=5 \\
\text { 10. } & \text { Surya Asri } 2 \mathrm{~B}=7\end{array}$ \\
\hline Hasil Cluster 4 & \multicolumn{2}{|c|}{ Hasil Cluster 5} \\
\hline $\begin{array}{l}\text { Terdiri dari } 33 \text { Balita yang } \\
\text { berasal dari, Posyandu: } \\
\text { 1. Ciro } 1=2 \\
\text { 2. Kedung } 1=12 \\
\text { 3. Jumput Wetan }=7 \\
\text { 4. Ciro } 2=1 \\
\text { 5. Citra Gading }=4 \\
\text { 6. Citra Surya Mas }=4 \\
\text { 7. Jumput Rejo Indah }=1 \\
\text { 8. Keling }=2 \\
\text { 9. Puri Sejahtera } 3=0 \\
\text { 10. Surya Asri } 2 \mathrm{~B}=0\end{array}$ & \multicolumn{2}{|l|}{$\begin{array}{l}\text { 1. Ciro } 1=1 \\
\text { 2. Kedung } 1=2 \\
\text { 3. Jumput Wetan }=1 \\
\text { 4. Ciro } 2=14 \\
\text { 5. Citra Gading }=0 \\
\text { 6. Citra Surya Mas }=0 \\
\text { 7. Jumput Rejo Indah = } 3 \\
\text { 8. Keling }=1 \\
\text { 9. Puri Sejahtera } 3=0 \\
\text { 10. Surya Asri } 2 B=0\end{array}$} \\
\hline
\end{tabular}

Dari data tabel 1. diatas dapat diinformasikan bahwa jumlah balita pada cluster $1=37$ balita dimana balita pada Posyandu Citra Gading memerlukan perhatian khusus karena terdapat 11 balita yang menderita gizi buruk. Pada cluster 2 jumlah balita yang mengalami gizi kurang sejumlah $=30$ balita terutama balita pada Posyandu Puri Sejahtera 3 yang jumlahnya 7 balita. Pada cluster 3 terdapat 28 balita dimana cluster ini masuk pada cluster gizi baik terutama pada balita di Posyandu Surya Asri 2 B sejumlah 7 orang. Sedangkan pada cluster 4 dimana masuk pada cluster gizi lebih berjumlah 33 balita dimana balita yang mengalami gizi lebih yaitu balita pada Posyandu Kedung 1. Serta pada cluster 5 yang merupakan cluster balita dengan obesitas terdapat sejumlah 22 balita terutama pada Posyandu Jumput Rejo Indah sejumlah 3 balita.

\subsection{Struktur Data}

Pengambilan data antropometri balita usia 0-59 bulan dengan 2 parameter yaitu berat badan menurut usia $(\mathrm{BB} / \mathrm{U})$ dan tinggi badan menurut usia $(\mathrm{TB} / \mathrm{U})$ yang diukur pada bulan Februari tahun 2020 berupa file excel yang berisi data balita sebanyak 150 data yang berasal dari posyandu yang ada di desa Jumput Rejo Sukodono Sidoarjo. Dataset ini dapat digunakan untuk keperluan penelitian

\footnotetext{
Amir Ali, [Clustering Data Antropometri Balita Untuk Menentukan Status Gizi Balita di Kelurahan Jumput Rejo Sukodono Sidoarjo]
} 


\subsection{Normalisasi Data}

Proses normalisasi data dengan menggunakan persamaan (2) [3]:

$$
\text { Nilai Normalisasi }=\frac{(\text { Nilai Awal }- \text { Nilai Minimum })}{(\text { Nilai Maksimal }- \text { Nilai Minimum })}
$$

Nilai variabel tinggi dan berat badan akan dinormalisasi ke dalam rentang 0-1. Adapun proses normalisasinya adalah

1. Mencari nilai maksimum dan minimum untuk variabel tinggi badan $(\mathrm{X})$

Nilai maksimum $($ Xmaks $)=110$

Nilai Minimum $(\mathrm{Xmin})=53$

2. Menghitung nilai normalisasi menggunakan persamaan di bawah ini

$$
\begin{aligned}
\mathrm{X} 11= & \frac{\text { Xbalita } 1-\text { Xmin }}{\text { Xmaks }- \text { Xmin }} \\
= & 60-53 \\
& 110-53 \\
= & 0,12 \\
\mathrm{X} 12= & \frac{\text { Xbalita2 }- \text { Xmin }}{\text { Xmaks }- \text { Xmin }} \\
= & 91-53 \\
& 110-53 \\
= & 0,67 \\
\mathrm{X} 13= & \frac{\text { Xbalita3 }- \text { Xmin }}{\text { Xmaks }- \text { Xmin }} \\
= & 97-53 \\
& 110-53 \\
= & 0,77
\end{aligned}
$$

Perhitungan yang sama dilakukan hingga balita ke 150 .

Tabel 2. Normalisasi Tinggi Badan Balita

\begin{tabular}{|l|c|l|l|}
\hline Balita & Ke- & $\begin{array}{c}\text { Tinggi Badan } \\
(\mathbf{c m})\end{array}$ & \multicolumn{1}{c|}{ Normalisasi Tinggi Badan } \\
\hline Balita & 1 & 60 & 0.12 \\
\hline Balita & 2 & 91 & 0.67 \\
\hline Balita & 3 & 97 & 0.77 \\
\hline Balita & 4 & 100 & 0.82 \\
\hline Balita & 5 & 71 & 0.32 \\
\hline Balita & 6 & 69 & 0.28 \\
\hline Balita & 7 & 110 & 1.00 \\
\hline Balita & 8 & 104 & 0.89 \\
\hline Balita & 9 & 96.5 & 0.76 \\
\hline Balita & 10 & 87 & 0.60 \\
\hline$\ldots \ldots \ldots$ & $\ldots \ldots$ & $\ldots \ldots \ldots \ldots \ldots \ldots \ldots \ldots \ldots \ldots \ldots \ldots \ldots \ldots \ldots \ldots \ldots \ldots \ldots \ldots \ldots \ldots \ldots \ldots \ldots \ldots \ldots \ldots \ldots \ldots \ldots \ldots$ \\
\hline Balita & 150 & 110 & 1.00 \\
\hline
\end{tabular}


Dengan cara yang sama juga diperoleh untuk menghitung normalisasi berat badan balita.

Tabel 3. Normalisasi Berat Badan Balita

\begin{tabular}{|c|c|c|c|}
\hline Balita & Ke- & Berat Badan (Kg) & Normalisasi Berat Badan \\
\hline Balita & 1 & 5.8 & 0.09 \\
\hline Balita & 2 & 12.6 & 0.40 \\
\hline Balita & 3 & 18.5 & 0.66 \\
\hline Balita & 4 & 16.7 & 0.58 \\
\hline Balita & 5 & 7.5 & 0.17 \\
\hline Balita & 6 & 7.6 & 0.17 \\
\hline Balita & 7 & 26 & 1.00 \\
\hline Balita & 8 & 16.7 & 0.58 \\
\hline Balita & 9 & 15.7 & 0.54 \\
\hline Balita & 10 & 11.8 & 0.36 \\
\hline$\ldots \ldots \ldots$ & $\ldots \ldots$ & . $\ldots \ldots \ldots \ldots \ldots \ldots \ldots \ldots$ & „ \\
\hline Balita & 150 & 17 & 0.60 \\
\hline
\end{tabular}

\subsection{Clustering Data}

Pada proses clusterisasi data ini, dimulai dari menentukan jumlah cluster yang akan dibentuk. Dari ke 150 data balita tersebut, maka akan dikelompokkan ke dalam 5 cluster yaitu Gizi Buruk, Gizi Kurang, Gizi Baik, Gizi Lebih dan Obesitas [17].

Setelah menentukan jumlah cluster, maka langkah selanjutnya adalah menentukan nilai initial cluster centre untuk masing-masing cluster pada setiap variabelnya. Nilai initial cluster centre ini diperoleh secara acak. Pada iterasi selanjutnya, nilai initial cluster centre (pengulangan ke-1 sampai posisi normal/maksimal iterasi) diberikan dengan menghitung nilai rata-rata data pada setiap clusternya. Jika nilai inisial cluster centre yang baru tidak sama dengan nilai inisial cluster centre awal maka proses iterasi dilanjutkan hingga nilai proses sama atau sampai dengan nilai maksimum iterasi yang telah ditetapkan sebelumnya (misal 100). Namun jika nilai initial cluster centre yang baru sama dengan initial cluster centre yang lama, maka proses pengelompokkan berhenti [8]

Pada pengolahan data penentuan status gizi balita:

1. Pada iterasi ke-1, menentukan initial cluster centre awal yang di pilih secara random:

Tabel 4. Nilai Initial Cluster Center Awal Secara Random

\begin{tabular}{|c|l|c|c|}
\hline Cluster & Status Gizi & Tinggi Badan $(\mathbf{C m})$ & Berat Badan $(\mathbf{K g})$ \\
\hline 1 & Gizi Buruk & 0.60 & 0.39 \\
\hline 2 & Gizi Kurang & 0.47 & 0.25 \\
\hline 3 & Gizi Baik & 0.51 & 0.24 \\
\hline 4 & Gizi Lebih & 0.88 & 0.43 \\
\hline 5 & Obesitas & 0.93 & 0.56 \\
\hline
\end{tabular}

\footnotetext{
Amir Ali, [Clustering Data Antropometri Balita Untuk Menentukan Status Gizi Balita di Kelurahan Jumput Rejo Sukodono Sidoarjo]
} 
2. Menghitung jarak data ke pusat cluster center

Persamaan yang digunakan untuk menghitung jarak pada penelitian ini adalah Euclidean Distance yang memiliki persamaan (1)

$$
\mathrm{d}=\sqrt{(x 1-x 2)^{2}+\left(y 1-y^{2}\right)^{2}}
$$

Contoh perhitungan jarak data ke-1 pada masing-masing cluster adalah:

$\mathrm{D}(\mathrm{x} 1, \mathrm{c} 1)=\sqrt{ }(\text { Tinggi Badan1 Hasil Normalisasi- Tinggi Badan Cluster1 })^{2}+$

(Berat Badan1 Hasil Normalisasi- Berat Badan Cluster1) ${ }^{2}$

$$
\begin{aligned}
& =\sqrt{ }(0,12-0,60)^{2}+(0,09-0,39)^{2} \\
& =0,56
\end{aligned}
$$

$\mathrm{D}(\mathrm{x} 1, \mathrm{c} 2)=\sqrt{ }(\text { Tinggi Badan1 Hasil Normalisasi- Tinggi Badan Cluster2 })^{2}+$

(Berat Badan1 Hasil Normalisasi- Berat Badan Cluster2) ${ }^{2}$

$$
\begin{aligned}
& =\sqrt{ }(0,12-0,47)^{2}+(0,09-0,25)^{2} \\
& =0.38
\end{aligned}
$$

$D(x 1, c 3)=\sqrt{ }(\text { Tinggi Badan1 Hasil Normalisasi- Tinggi Badan Cluster3 })^{2}+$

(Berat Badan1 Hasil Normalisasi- Berat Badan Cluster3) ${ }^{2}$

$$
\begin{aligned}
& =\sqrt{ }(0,12-0,51)^{2}+(0,09-0,24)^{2} \\
& =0,42
\end{aligned}
$$

$\mathrm{D}(\mathrm{x} 1, \mathrm{c} 4)=\sqrt{ }(\text { Tinggi Badan1 Hasil Normalisasi- Tinggi Badan Cluster3 })^{2}+$

(Berat Badan1 Hasil Normalisasi- Berat Badan Cluster3) ${ }^{2}$

$$
\begin{aligned}
& =\sqrt{ }(0,12-0,88)^{2}+(0,09-0,43)^{2} \\
& =0,83
\end{aligned}
$$

$\mathrm{D}(\mathrm{x} 1, \mathrm{c5})=\sqrt{ }(\text { Tinggi Badan1 Hasil Normalisasi- Tinggi Badan Cluster3 })^{2}+$

(Berat Badan1 Hasil Normalisasi- Berat Badan Cluster3) $^{2}$

$$
\begin{aligned}
& =\sqrt{ }(0,12-0,93)^{2}+(0,09-0,56)^{2} \\
& =0,94
\end{aligned}
$$

Tabel 5. Jarak Data pada Tiap Cluster

\begin{tabular}{|l|c|c|c|c|c|}
\hline Nama & Jarak C1 & Jarak C2 & Jarak C3 & Jarak C4 & Jarak C5 \\
\hline Balita 1 & 0,56 & 0,38 & 0,42 & 0,83 & 0,94 \\
\hline Balita 2 & 0,07 & 0,25 & 0,27 & 0,21 & 0,31 \\
\hline Balita 3 & 0,32 & 0,51 & 0,50 & 0,25 & 0,19 \\
\hline Balita 4 & 0,29 & 0,48 & 0,46 & 0,16 & 0,11 \\
\hline Balita 5 & 0,36 & 0,17 & 0,20 & 0,62 & 0,72 \\
\hline Balita 6 & 0,39 & 0,21 & 0,24 & 0,65 & 0,76 \\
\hline Balita 7 & 0,73 & 0,92 & 0,90 & 0,58 & 0,45 \\
\hline Balita 8 & 0,35 & 0,53 & 0,51 & 0,15 & 0,05 \\
\hline Balita 9 & 0,22 & 0,41 & 0,39 & 0,16 & 0,17 \\
\hline Balita 10 & 0,03 & 0,17 & 0,15 & 0,29 & 0,39 \\
\hline Balita 11 & 0,01 & 0,18 & 0,17 & 0,28 & 0,38 \\
\hline Balita 12 & 0.08 & 0,17 & 0,11 & 0,36 & 0,45 \\
\hline Balita 13 & 0,06 & 0,25 & 0,23 & 0,23 & 0,31 \\
\hline Balita 14 & 0,11 & 0,08 & 0,08 & 0,39 & 0,48 \\
\hline Balita 15 & 0,19 & 0,29 & 0,26 & 0,16 & 0,27 \\
\hline
\end{tabular}

Perhitungan diatas dilakukan juga untuk ke 150 data yang lain, sehingga akan didapatkan jarak tiap data pada masing-masing clusternya.

\footnotetext{
Amir Ali, [Clustering Data Antropometri Balita Untuk Menentukan Status Gizi Balita di Kelurahan Jumput Rejo Sukodono Sidoarjo]
} 


\section{Pengelompokkan data ke dalam clusternya}

Setelah masing-masing data dihitung jaraknya untuk setiap cluster, langkah selanjutnya adalah mengelompokkan data sesuai dengan clusternya. Pada contoh diatas untuk data ke-1 dapat dikelompokkan pada cluster 2 karena jaraknya yang paling terdekat dengan pusat cluster pada cluster 2 yaitu 0,38 sedangkan yang lain terlalu jauh misalnya pada pusat cluster 1 yaitu jaraknya 0,56 , pada cluster 3 yaitu jaraknya 0,42 , pada cluster 4 yaitu jaraknya 0,83 dan pada cluster 5 yaitu jaraknya 0,94 . Sehingga jarak yang paling dekat untuk data ke-1 dengan pusat clusternya adalah jarak ke pusat cluster 2 sehingga data ke-1 dapat dikelompokkan ke dalam cluster 2. Dengan cara yang sama kita dapat mengelompokkan data tersebut sampai data ke 150.

Tabel 6. Penempatan Data pada Cluster Dengan Jarak Terdekat

\begin{tabular}{|l|l|l|l|l|l|}
\hline Nama & Jarak C1 & Jarak C2 & Jarak C3 & Jarak C4 & Jarak C5 \\
\hline Balita 1 & & $*$ & & & \\
\hline Balita 2 & $*$ & & & & \\
\hline Balita 3 & & & & & $*$ \\
\hline Balita 4 & & & & & $*$ \\
\hline Balita 5 & & $*$ & & & \\
\hline Balita 6 & & $*$ & & & \\
\hline Balita 7 & & & & & $*$ \\
\hline Balita 8 & & & & & $*$ \\
\hline Balita 9 & & & & $*$ & \\
\hline Balita 10 & $*$ & & & & \\
\hline Balita 11 & $*$ & & & & \\
\hline Balita 12 & $*$ & & & & \\
\hline Balita 13 & $*$ & & & & \\
\hline Balita 14 & & & $*$ & & \\
\hline Nama & Jarak C1 & Jarak C2 & Jarak C3 & Jarak C4 & Jarak C5 \\
\hline Balita 15 & & & & $*$ & \\
\hline
\end{tabular}

Pengelompokkan diatas dilakukan juga untuk ke 150 data yang lain, sehingga akan didapatkan tiap data pada masing-masing clusternya.

4. Penentuan pusat cluster baru

Setelah mengelompokkan data ke dalam pusat cluster awal yang terdekat, maka langkah selanjutnya menentukan pusat cluster baru dengan cara dihitung berdasarkan data anggota tiaptiap cluster yang sudah didapatkan dengan menggunakan persamaan (3):

$$
\mathrm{Ci}=\frac{1}{M} \sum_{j=1}^{M} X j
$$

Dimana: dilakukan penjumlahan data yang menjadi anggota clusternya dibagi sebanyak data anggota clusternya, maka akan didapatkan titik pusat cluster yang baru

Misalnya dari pengelompokan ke 15 data diatas, maka titik pusat cluster yang baru untuk variabel tinggi badan adalah:

$$
\begin{aligned}
& \mathrm{C} 1 \mathrm{~TB}=(0,67+0,60+0,60+0,53+0,65) / 5=0,61 \\
& \mathrm{C} 2 \mathrm{~TB}=(0,12+0,32+0,28) / 3=0,24 \\
& \mathrm{C} 3 \mathrm{~TB}=(0,51) / 1=0,51 \\
& \mathrm{C} 4 \mathrm{~TB}=(0,76+0,72) / 2=0,74 \\
& \mathrm{C} \text { TTB }=(0,77+0,82+1+0,89) / 4=0,87
\end{aligned}
$$

\footnotetext{
Amir Ali, [Clustering Data Antropometri Balita Untuk Menentukan Status Gizi Balita di Kelurahan Jumput Rejo Sukodono Sidoarjo]
} 
Cara yang sama dapat dilakukan untuk menghitung titik pusat cluster yang baru untuk variabel berat badan

Tabel 7. Pusat Cluster Baru

\begin{tabular}{|c|l|c|c|}
\hline Cluster & Status Gizi & Tinggi Badan $(\mathbf{C m})$ & Berat Badan $(\mathbf{K g})$ \\
\hline 1 & Gizi Buruk & 0.61 & 0.38 \\
\hline 2 & Gizi Kurang & 0.24 & 0.14 \\
\hline 3 & Gizi Baik & 0.51 & 0.32 \\
\hline 4 & Gizi Lebih & 0.74 & 0.47 \\
\hline 5 & Obesitas & 0.87 & 0.71 \\
\hline
\end{tabular}

Iterasi selanjutnya dilakukan dengan cara yang sama hingga tidak ada perubahan data dalam suatu cluster [18]

\section{KESIMPULAN}

Dari hasil penelitian ini didapatkan hasil pengelompokkan data antropometri balita di desa jumput rejo sukodono menunjukkan bahwa terdapat bayi dengan status gizi buruk sebanyak 37 balita, gizi kurang sebanyak 30 balita, gizi baik sebanyak 28 balita, gizi lebih sebanyak 33 balita dan 22 balita mengalami obesitas dari total 150 data antropometri balita. Analisa data antropometri balita ini dengan menggunakan $K$-Means clustering dimana dibentuk dari 5 cluster untuk 2 variabel yang digunakan yaitu berat badan dan tinggi badan. Pengelompokan data antropometri balita dari proses data mining diatas adalah untuk menghasilkan informasi baru mengenai pola pengelompokan data antropometri balita di desa Jumput Rejo Sukodono Sidoarjo. Hal ini dapat dijadikan acuan bagi puskesmas lewat bidan dan tenaga kesehatan yang terlatih untuk melakukan sosialisasi dan pencegahan terhadap gizi buruk balita berdasarkan tinggi badan dan berat badan balita.

\section{SARAN}

Perlu perbandingan hasil pengelompokkan data antropometri balita dalam menentukan status gizi balita dengan metode pengelompokkan lainnya. Berdasarkan pengujian akurasi dilakukan dengan membandingkan pengelompokkan hasil $K$-Means dengan pengelompokkan yang dilakukan oleh petugas gizi puskesmas dengan menggunakan nilai $\mathrm{Z}$-Score (WHO-2005) dimana diperoleh hasil 19 data antropometri balita dengan hasil pengelompokkan yang sama, sehingga tingkat keakuratan kebenaran algoritma $K$-Means dalam pengelompokkan status gizi balita sebesar $19 / 150=13 \%$. Tingkat keakuratan metode $K$-Means untuk menentukan status gizi balita termasuk rendah. Oleh karena itu perlu di uji cobakan metode yang lain yang memiliki tingkat keakuratan yang lebih baik 


\section{UCAPAN TERIMA KASIH}

Penulis mengucapkan terima kasih kepada Stikes Yayasan Rumah Sakit Dr.Soetomo yang telah memberi dukungan financial terhadap penelitian ini.

\section{DAFTAR PUSTAKA}

[1] F. I. Supariasa, IDN, Bakri Bachyar, 2002, Penilaian Status Gizi, EGC, Jakarta

[2] J. I. C. A. Soetjiningsih, 2016. Departemen Kesehatan, Petunjuk Teknik Penggunaan Buku Kesehatan Ibu dan Anak. Jakarta.

[3] S. S. Irfiani, Eni. Rani, 2018, "Algoritma K-Means Clustering Untuk Menentukan Nilai Gizi Balita,” Justin Sist. dan Teknol. Inf., Vol. 6, p. 168.

[4] L. Daniel, 2005. Discovery Knowledge in Data, A Jhon Wiley \& Sons, Inc Publication. Canada.

[5] H. L. S. Metisen, Benri Melpa, 2015, "Analisis Clustering Menggunakan Metode KMeans Dalam Pengelompokkan Penjualan Produk pada Swalayan Fadhila," J. Media Infotama, Vol. Volume 11.

[6] A. T. dan F. K. S. Agustina, D. Yhudo, H. Santoso, N. Marnasusanto, 2012, "Clustering Kualitas Beras Berdasarkan Ciri Fisik Menggunakan Metode K-Means," [Online]. Available:http://yudistira.lecture.ub.ac.id/files/2014/04/clustering-kualitas-beras-dengank-means.pdf.

[7] J. O. Ong, 2013, "Implementasi Algoritma K-Means Clustering Untuk Menentukan Strategi Marketing President University," J. Ilm. Tek. Ind., Vol. 12 No 1, pp. 10-20.

[8] A. K. Nalendra, 2018, "Pengukuran Keakuratan Metode K-Means Untuk Menentukan Status Gizi Balita,” Ekon. dan Tek. Inform., Vol. 6, p. 52.

[9] E. Prasetyo, 2012, Data Mining Konsep dan Aplikasi Menggunakan Matlab. Andi Yogyakarta.

[10] B. Pavel, 2002, Survey of Clustering Data Mining Techniques.

[11] Y. Agusta, 2007, “K-Means - Penerapan, Permasalahan dan Metode Terkait," Sist. dan Inform., Vol. 3, pp. 47-60.

[12] S. U, Fayyad, G, Piatetsky-Shapiro, P, 1996, Advances in Knowledge Discovery and Data Mining.

[13] R. D. Mardiana, Tari. Nyoto, 2015, "Kluster Bag-of-Word Menggunakan Weka," Edukasi dan Penelit. Inform, Vol. 1, p. 2. 
[14] I. S. M. Silitonga, D Parasian, 2017, "Klusterisasi Pola Penyebaran Penyakit Pasien Berdasarkan Usia Pasien Dengan Menggunakan K-Means Clustering.," Times Technol. informatics Comput. Syst., Vol. VI No.2.

[15] H. L. S. Metisen, Benri Melpa, 2015, "Analisis Clustering Menggunakan Metode KMeans Dalam Pengelompokkan Penjualan Produk pada Swalayan Fadhila," J. Media Infotama, Vol. 11 No.2, p. 111.

[16] P. R. N. Chusyairi, Ahmad. Saputra, 2019, "Pengelompokan Data Puskesmas Banyuwangi Dalam Pemberian Imunisasi Menggunakan Metode K-Means Clustering," Telematika, Vol. 12, p. 142.

[17] W. M. P. Dhuhita, 2015, "Clustering Menggunakan Metode K-Means Untuk Menentukan Status Gizi Balita," Informatika, Vol. 15, p. 166.

[18] A. K. Wardhani, 2016, "Implementasi Algoritma K-Means Untuk Pengelompokkan Penyakit Pasien pada Puskesmas Kajen Pekalongan," Transformatika, Vol. 14, p. 35. 